\title{
Ordering the city: revolution, modernity and road renaming in Shanghai, 1949-1966
}

\author{
Jonathan J. Howlett ${ }^{\star \dagger}$ (D) \\ Department of History, University of York, Heslington, York, YO10 5DD, UK \\ ${ }^{*}$ Corresponding author. Email: jon.howlett@york.ac.uk
}

\begin{abstract}
Between 1949 and 1966, the Chinese Communist Party (CCP)-led municipal government of Shanghai renamed more than one in seven of the city's roads. Renaming was an important marker of revolutionary change in China's largest and most foreign-influenced city. Road renaming in socialist China has been commonly understood to have been extensive. This article argues, however, that the nature and extent of renaming in socialist Shanghai was less dramatic than has been assumed. It demonstrates that renaming was not simply an iconoclastic process, but rather involved the pragmatic weighing of symbolic change against potential disruption. Further, it contends that renaming was driven by a desire to order the city, in line with the CCP's modernist worldview.
\end{abstract}

In May 1966, the Shanghai Municipal Construction Bureau received a letter from a Comrade Lu Liang. The letter drew attention to the plight of the residents of Laji Tang (Rubbish Pool) Street in Yangjiadu district, Pudong. ${ }^{1}$ Today, Pudong, on the eastern bank of the Huangpu River, is a hyper-modern business hub, boasting a futuristic crowd of skyscrapers. In 1966, the area was a muddle of warehouses and slums. Across the river sat the grand neo-classical architecture of the skyscrapers and banks that lined the city's famous Bund, which had been constructed in the century that had followed Shanghai's opening as a treaty port in 1843. Shanghai had been at the heart of colonial activity in China. It had become the largest city in Asia: an industrial and commercial powerhouse, dwarfing all competitors with its sprawling growth, ostentatious wealth and extremes of inequality. Amongst the legions of migrants drawn to the metropolis were the residents of Rubbish

\footnotetext{
${ }^{\dagger}$ I am grateful to Oleg Benesch, Robert Bickers, David Clayton, Christian Henriot and Koji Hirata for their insightful comments on drafts of this article, and Liu Yajuan for her assistance with materials. Urban History's anonymous reviewers provided thoughtful suggestions. This paper was presented at the Oxford China Centre in June 2020. The author would like to thank the organizers and attendees.

${ }^{1}$ Shanghai Municipal Archives (SMA) B11-2-145-14, Shanghai Shi Chengshi Jianshe Ju guanyu genggai Laji Tang Jie luming de qingshi baogao, 17 May 1966.

(C) The Author(s), 2021. Published by Cambridge University Press. This is an Open Access article, distributed under the terms of the Creative Commons Attribution licence (http://creativecommons.org/licenses/by/4.0/), which permits unrestricted re-use, distribution, and reproduction in any medium, provided the original work is properly cited.
} 
Pool Street, squatters who lived in ramshackle buildings. ${ }^{2}$ Comrade Lu expressed incredulity that, 17 years after the foundation of the People's Republic of China (PRC) in October 1949, the name Rubbish Pool Street remained unchanged, despite being an obvious legacy of the old society's contempt for the poor. ${ }^{3}$ This article joins Comrade Lu in questioning how this unfavourable name persisted for so long in socialist Shanghai. It argues for a reappraisal of the nature and extent of revolutionary transformation in urban China, through the issue of road renaming. It concludes that renaming was constrained by logistical factors and the Chinese Communist Party (CCP)'s wish to avoid disruption. In addition, renaming was motivated by another aspect of socialist ideology: a desire to order the city in the name of modernity and production.

As Marxists, the CCP's leadership believed that the character of Shanghai had been degraded by the 'semi-feudal and semi-colonial' economic and social structures that had shaped its development over the previous hundred years, as well as by the 'reactionary' rule of their predecessors, the Guomindang (Nationalist Party) government of 1927-49. 'Liberation' (the CCP's term), in May 1949, was portrayed as an epochal transformation, marking the birth of a 'New Shanghai'. The CCP's propaganda presented the city as the site of a symbolic battle against the legacies of the exploitative old society, and as a showcase for the power of socialism to lift people from immiseration. ${ }^{4}$ The counternarrative to this rosy picture, promoted by overseas observers, including many who had known Shanghai before 1949, focused on the extremes of violence and disorder that characterized the Maoist period as mass mobilization campaigns were deployed to reorder society, with devastating human costs. ${ }^{5}$ In the context of both characterizations, we might perhaps join Comrade Lu in wondering why a trivial matter such as changing the name of Rubbish Pool Street went unaddressed for so long.

Historical geographers have shown that 'spatial inscription' (giving names to places) is an important mechanism by which governments assert social and political control. ${ }^{6}$ The field of critical toponymy has explored place renaming as an activity that creates cultural tension, as officials attempt to inscribe dominant political and cultural ideologies onto cities in moments of transformation. ${ }^{7}$ Revolutionaries across the globe have used toponymic renaming to reinforce temporal breaks with the past, distinguishing the 'new' society from the 'old'. Inscription of new names on signs, maps and other documentation has been a universally significant way in which radical political ideology has been manifested in

\footnotetext{
${ }^{2} \mathrm{C}$. Henriot, 'Slums, squats, or hutments? Constructing and deconstructing an in-between space in modern Shanghai (1926-65)', Frontiers of History in China, 7 (2012), 499-528.

${ }^{3} \mathrm{SMA}$ B11-2-145-14.

${ }^{4}$ Shanghai jiefang shi nian bianji weiyuanhui, Shanghai Jiefang Shi Nian (Ten Years of Liberated Shanghai) (Shanghai, 1960).

${ }^{5}$ Zheng Nian's bestselling memoir Life and Death in Shanghai is representative this type of account: Nien Cheng, Life and Death in Shanghai (London, 1988).

${ }^{6} \mathrm{R}$. Rose-Redwood, D. Alderman and M. Azaryahu, 'Geographies of toponymic inscription: new directions in critical place-name studies', Progress in Human Geography, 34 (2010), 453-70.

${ }^{7}$ Representative works include R.S. Rose-Redwood, 'From number to name: symbolic capital, places of memory and the politics of street renaming in New York City', Social \& Cultural Geography, 9 (2008), 431-52; and M. Azaryahu, 'The politics of commemorative street renaming: Berlin 1945-1948', Journal of Historical Geography, 374 (2011), 483-92.
} 
ordinary people's lives. ${ }^{8}$ In the Soviet Union, almost half of all place names were 'Sovietized' after 1917..$^{9}$ Similarly, the French revolutionaries of 1789 had changed place names in a burst of iconoclasm, rejecting Christian or monarchist forms in favour of revolutionary appellations. ${ }^{10}$ In some regards, renaming in Maoist China (1949-76) followed similar patterns with widescale renaming taking place across the country to eliminate references to former regimes, old culture and colonial legacies, in accordance with the CCP's socialist and nationalistic ideology. Nowhere was this process more marked than in the city of Shanghai. These renaming processes have, however, received little attention from historians. ${ }^{11}$

Between 1949 and the beginning of the Great Proletarian Cultural Revolution (1966-76), the CCP-led municipal government of Shanghai renamed around 220 of the city's roads. ${ }^{12}$ This amounted to more than one in seven of the approximately 1,400 roads in Shanghai in $1964 .^{13}$ Renaming was one part of a broader process of urban transformation that reshaped Asia's most well-known former treaty port. While recognizing that renaming is an important symbolic act, this article uses the issue of road renaming to argue for more nuanced understanding of the nature and pace of revolutionary change in socialist Shanghai. It will demonstrate that a substantial proportion of road names changed in the period 1949 to 1966 were renamed for administrative rather than revolutionary reasons. Renaming was constrained by both ideological and logistical factors, the investigation of which exposes neglected aspects of the broader Communist project and its impacts on urban life.

In urban history, it remains common to present the Maoist era as three decades of decline and disruption, and as an interregnum, in which the city was diverted away from its natural course of prosperity and growth. One frequently cited study describes socialist Shanghai as a 'political morass' governed only by 'vague doctrines', and the CCP's plans for urban development are said to have become 'purely symbolic gestures of progress in a political environment that disfavoured improvement based on anything but political ideology' ${ }^{14}$ This characterization of

\footnotetext{
${ }^{8}$ B.S.A. Yeoh, 'Street names in colonial Singapore', Geographical Review, 82 (1992), 313-22.

${ }^{9} \mathrm{~A}$. Marin, 'Bordering time in the cityscape. Toponymic changes as temporal boundary-making: street renaming in Leningrad/St. Petersburg', Geopolitics, 17 (2012), 192-216.

${ }^{10}$ P. McPhee, The French Revolution, 1789-1799 (Oxford, 2002), 137-8.

${ }^{11}$ Existing works have mostly focused on the meaning of place names, rather than renaming processes: Huang Wenchuan, 'A comparison of politics of street names in Taipei and Shanghai', in Ding Yannan, Maurizio Marinelli and Zhang Xiaohong (eds.), China: A Historical Geography of the Urban (Cham, 2018), 137-61; Li Huajun, 'Zhongguo chengshi jieming zhengzhi secai chuyi' (A preliminary study on political street names in China), Xidian University MA diss., 2002; Yao Xiaoyi and Cai Junmei, 'Shanghai chengshi jiedao mingming de yuyan liju yanjiu' (The study of linguistic motivation for naming Shanghai streets and roads (sic)), Journal of Hebei University (Philosophy and Social Science), 33 (2012), 150-3; Zhang Baojun, 'Shanghai jiedao mingcheng de renwen jiazhi yanjiu' (Study on the humanistic value of Shanghai road names (sic)), Journal of Shanghai University of Electric Power, 30 (2014), 81-2.

${ }^{12}$ Shanghai diming zhi bianzuan weiyuanhui (eds.), Shanghai Diming Zhi (hereafter SDZ) (Gazeteer of Shanghai Place Names) (Shanghai, 1998), ch. 7, sect. 2. URL: www.shtong.gov.cn/Newsite/node2/ node2245/node70862/index.html, accessed 27 Jul. 2020.

${ }^{13}$ SMA B11-1-12-157, Shanghai Shi Chengshi Jianshi Ju guanyu genggai Shanghai shi bufen fengjian mixin he zhimindi canyi luming de qingshi baogao (cao'an), 20 May 1964.

${ }^{14}$ E. Denison and Guang Yu Ren, Building Shanghai: The Story of China's Gateway (Hoboken, NJ, 2013; first publ. 2006), unnumbered ebook: 'Communist Liberation' section.
} 
urban change in Maoist China runs counter to wider trends in the field of PRC history. In recent years, a new history of the PRC has emerged that challenges historians' traditional emphasis on high politics and disastrous political campaigns in the Mao era. ${ }^{15}$ Jeremy Brown has stressed the importance of acknowledging the unintended consequences of the CCP's revolutionary modernization project, especially at the grassroots where local officials adapted policy and compromised with local society when implementing instructions from the central government. ${ }^{16}$ Crucially for this study, newer scholarship emphasizes the need to avoid teleology in retelling the history of the PRC, taking each development on its own terms. ${ }^{17}$ This is particularly important when it comes to understanding how the chaotic iconoclasm of the Cultural Revolution has cast a long shadow over the history of Maoist Shanghai, shaping ideas about the nature and extent of revolutionary transformation throughout the whole socialist period. ${ }^{18}$ In August 1966, Mao Zedong (1893-1976) called on young Red Guards to 'bombard the headquarters', unleashing their fury on so-called 'capitalist roaders' within the government. The wanton destruction that followed has endured in historiography and popular memory, conditioning the way we view the Chinese revolution more widely. In regard to road names, social theorist Michel Dutton has described the CCP as 'the past masters of renaming and remapping', suggesting that the spatial worlds in which ordinary people lived were completely reshaped during the Cultural Revolution as Red Guards renamed roads on a massive scale throughout China, writing that: 'one could not think of going home or going out without "going red", for virtually every street name demanded it'. ${ }^{19}$

Before the Cultural Revolution, however, this was not the case. It is important, therefore, to understand how and when renaming occurred in socialist Shanghai, and how revolutionary change interplayed with the necessities of quotidian administration. ${ }^{20}$ Political radicalism and revolutionary symbolism played important roles in road renaming, but the CCP were also driven by a desire to impose order on the urban environment. The CCP was (and remains) a high-modernist movement that prioritized order and rationality in the name of production. ${ }^{21}$

Communism, like all ideas, must be understood in context. As Christian Henriot has shown, overcrowded living conditions, bad sanitation and poorly regulated workplaces made life in pre-revolution Shanghai extremely deadly to those without

\footnotetext{
${ }^{15}$ J. Brown and M.D. Johnson (eds.), Maoism at the Grassroots (Cambridge, MA, 2015); Zhang Jishun, Yuanqu de Dushi: 1950 Niandai de Shanghai (Beijing, 2015).

${ }^{16}$ J. Brown, City versus Countryside in Mao's China: Negotiating the Divide (Cambridge, 2012).

${ }^{17}$ N.J. Diamant, 'Policy blending, fuzzy chronology, and local understandings of national initiatives in early 1950s China', Frontiers of History in China, 9 (2014), 83-101.

${ }^{18}$ On the afterlife of the Cultural Revolution, see L. Dittmer, 'Rethinking China's Cultural Revolution amid reform', in Woei Lien Chong (ed.), China's Great Proletarian Cultural Revolution: Master Narratives and Post-Mao Counternarratives (Lanham, 2002), 3-26.

${ }^{19} \mathrm{M}$. Dutton, 'Street scenes of subalternity: China, globalization, and rights', Social Text, 60 (1999), $63-86,70-2$.

${ }^{20}$ On the importance of nuanced periodization and the need to track change over time in the history of socialist China, see Wang Di, The Teahouse under Socialism: The Decline and Renewal of Public Life in Chengdu, 1950-2000 (New York, 2018), 20.

${ }^{21}$ See A. Ghosh, Making It Count: Statistics and Statecraft in the Early People's Republic of China (Princeton, 2020).
} 
privilege. ${ }^{22}$ The CCP's goal was to elevate ordinary people through radical social transformation. Urban governance was always geared towards this aim. ${ }^{23}$ Shanghai never became a workers' utopia, but the idea of improvement was an important facet of CCP urban governance. As Lu Hanchao observes, for example, public green space in the city expanded by a factor of six in the eight years after 1949. Mao-era Shanghai was a place where there were regular and impressive flower shows, as well as mass campaigns. ${ }^{24}$ In addition, Communist officials understood that all effective states must rationalize and survey the societies they govern. ${ }^{25}$ For a city to be 'legible' to government, road names must be widely accepted by citizens and formally recognized on maps, signs and the paperwork that (to follow Bruno Latour) reduces the complexity of the city down to easily digestible lists and statistics for administrators. ${ }^{26}$

Beyond this emphasis on rationality, exploring the limits of revolutionary change through road renaming allows us to appreciate the many ways in which quotidian life in Shanghai continued to be shaped by the city's past. ${ }^{27}$ Road renaming was not used to turn Shanghai 'red', instead old names were replaced with references to Chinese cities, provinces and other geographical features, including mountains and rivers. This process of writing the nation onto Shanghai's streets had obvious advantages for a government that promoted nationalism as a source of its legitimacy. It is worth noting, however, that in so doing the new authorities followed a pattern established by the administrators of the city's former International Settlement in the 1860 s. $^{28}$

Shanghai had already witnessed widescale renaming in the 1940s, when previous governments had sought to eliminate the legacies of the imperialist past. These changes had caused great confusion. In contrast, renaming was kept to a minimum in the early 1950s, and was targeted at eliminating only the most obviously inappropriate references to the old order. Two rounds of renaming came in 1954 and 1958, as part of efforts to reshape the city in response to radical policies launched by the central government with the aim of moving China towards Communism: the General Line for the Transition to Socialism (1953-56) and the Great Leap Forward (1958-62). In both cases, the motive behind renaming was to systematize road names, making the cityscape more rational in the name of production. As part of this effort, politically inappropriate names were characterized as cultural impediments to production.

\footnotetext{
${ }^{22}$ C. Henriot, Scythe and the City: A Social History of Death in Shanghai (Stanford, 2016), 359-65.

${ }^{23}$ On PRC-era urban governance, see D.Y. Ho, Curating Revolution: Politics on Display in Mao's China (Cambridge, 2018); Lu Hanchao, 'Shanghai flora: the politics of urban greening in Maoist China', Urban History, 45 (2018), 60-102; Zhu Qian, 'Shanghai's socialist suburbanization 1953-1962', Journal of Planning History, 17 (2018), 226-47.

${ }^{24} \mathrm{Lu}$, 'Shanghai flora', 669-70.

${ }^{25}$ On 'legibility', see J.C. Scott, Seeing like a State: How Certain Schemes to Improve the Human Condition Have Failed (New Haven, 1998).

${ }^{26}$ B. Latour, Science in Action: How to Follow Scientists and Engineers through Society (Cambridge, MA, 1987), 215-37.

${ }^{27} \mathrm{Lu}$ Hanchao has suggested that life in the Maoist period was defined by the 'continuous ubiquity of traditionalism': Lu Hanchao, Beyond the Neon Lights: Everyday Shanghai in the Early Twentieth Century (Berkeley, 1999), 315-22.

${ }^{28}$ Huang, 'Politics of street names'.
} 
Renaming efforts followed a pattern whereby officials identified a need for widescale transformation, but baulked at the disruption that this might cause. This was even the case in the most radical round of road renaming in 1964, when the Socialist Education Movement (1962-66), a campaign to promote new standards of revolutionary behaviour, reached Shanghai. Renaming in 1964 focused on 'superstitious' names with religious connotations. The Movement laid the ideological groundwork for the Cultural Revolution, during which Red Guards took renaming into their own hands. Chaos ensued. The nation was set on a new course of 'reform and opening up' in 1978, following Mao's death in 1976. Against the backdrop of some of the most rapid urban growth in human history, the local government placed renewed emphasis on making Shanghai's road names 'legible' through the creation of a place name management infrastructure, as well as meticulous surveys and mapping. This emphasis on rationality echoed urban administration policies from the period 1949-66. We will begin by exploring the longer history of road renaming in Shanghai, showing how patterns of naming were established by the city's colonial administrators, and how the CCP's predecessors sought to transform the city through widescale renaming.

\section{Shanghai's road names, 1843-1949}

Shanghai was unique among Chinese cities in the scale of its foreign settlement areas, and in the influence of European and American-style architecture on its urban landscape. ${ }^{29}$ Before 1949 , successive administrations had used road renaming to inscribe their own identities onto the urban landscape, creating a semiotics of authority, and laying claim to the loyalities of its citizens. The first foreign settlers had arrived in Shanghai in 1843, following the signing of the Treaty of Nanking the previous year. American, British and French settlements were established on the western bank of the Huangpu, north of the walled Chinese city. In 1863, the British and American settlements merged to form an International Settlement governed by the Shanghai Municipal Council (established 1854). Thereafter, Shanghai was divided under three territorially distinct administrative regimes: the Chinese City, French Concession and International Settlement. The Settlement's thriving textile industry, extensive factory districts and sprawling docklands made it an economic dynamo. Chinese migrants readily embraced the relative security and economic opportunities the foreign concessions offered. ${ }^{30}$

Shanghai's distinctive geography was reflected in its road names. Road building in the Settlement began with spontaneous and unregulated private initiatives, but gradually came to be the preserve of the Council. In 1862, the Council decided that road names should be made intelligible to Shanghai's Chinese population, which had grown rapidly as refugees sought shelter from the Taiping Rebellion. Under this scheme, major roads running westwards from the riverfront were named after Chinese cities and north-south roads after provinces and counties. Those changed included Bridge, Church, Consulate and Sikh Roads, which became Sichuan, Jiangxi, Beijing and Guangxi Roads respectively. However, other roads

\footnotetext{
${ }^{29}$ C. Roskam, Improvised City: Architecture and Governance in Shanghai, 1843-1937 (Seattle, 2019).

${ }^{30}$ I. Jackson, Shaping Modern Shanghai: Colonialism in China's Global City (Cambridge, 2018).
} 
continued to be named after local landmarks (such as the Bund, Cemetery Road and Race Club Road), or prominent members of the foreign community. Gordon Road, for example, was named for General Charles Gordon (1833-85), who commanded the Ever Victorious Army against the Taipings. In 1922, the Council ruled that road names should seldom be changed, and that it was more appropriate and convenient to use Chinese names over foreign ones. ${ }^{31}$

The French preferred functional names (Rue de l'Administration, Rue du Consulat), and references to local landmarks. Naming was haphazard and included a mixture of Chinese and French names until 1906, when a major reorganization eliminated the former. In 1921, 25 roads were renamed after French military leaders from the 1914-18 war (Avenue Foch, Avenue Joffre, Avenue Pétain, etc.). ${ }^{32}$ The cornucopia of names in different languages across the city posed real administrative challenges. ${ }^{33}$ Some roads acquired alternative names among different language communities: Nanjing Road, the Settlement's most famous shopping street, was known by Chinese residents as the Da malu or 'main road'. ${ }^{34}$

In 1927, the Chinese-administered regions of Shanghai came under the rule of the National Government (1927-49), a dictatorship dominated by the Guomindang and its leader Jiang Jieshi (1887-1975, aka Chiang Kai-shek). The National Government's urban policy was designed to show the world that China could govern modern cities. In July 1929, development began of a new administrative centre in Jiangwan, to the north-east of the concessions, which was intended as a grand showcase for Chinese municipal governance. ${ }^{35}$ More than 130 new roads were laid out as part of this 'Greater Shanghai Plan', with several major new thoroughfares linking the development to the city centre, each of which was named after a founding father of the Guomindang. This included: Sun Zhongshan (1866-1925, aka Sun Yat-sen), the party's founder and first president of the Republic of China; Huang Xing (1874-1916), the early Republic's commander-in-chief; and Chen Qimei (1878-1916), a martyred co-founder. ${ }^{36}$ Other new roads were named after aspects of Guomindang ideology, typically featuring one or more of the three characters Guo (nation), Min (the people) and Zheng (government): Guo signified the government and party; Min referred to Sun Zhongshan's 'Three People's Principles' that formed the core of Guomindang ideology (Minzu (nationalism), Minquan (democracy) and Minsheng (the people's livelihood)); and Zheng was synonymous with the National Government. ${ }^{37}$ The project was

\footnotetext{
${ }^{31}$ J. Shen, 'Shanghai road nomenclature embodies history of city', The China Press, 25 Nov. 1933. These roads were known as Szechuan Road, Kiangsi Road, Peking Road and Kwangsi Road at the time under the Wade Giles system of transliteration. Sikh Road had once housed the barracks for Sikh policemen.

${ }^{32} \mathrm{P}$. French, The Old Shanghai A-Z (Hong Kong, 2010), 48-71, 182-4.

${ }^{33}$ R. Bickers, 'Incubator city: Shanghai and the crises of empires', Journal of Urban History, 38 (2012), $862-78$.

${ }^{34}$ A.H. Gordon, Streets of Shanghai: A History in Itself (Shanghai, 1941), 9.

${ }^{35}$ K.L. MacPherson, 'Designing China's urban future: the Greater Shanghai Plan, 1927-1937', Planning Perspective, 5 (1990), 39-62.

${ }^{36} \mathrm{SDZ}$, Dashiji (Chronicle of Events). Beyond naming new roads, the Guomindang did not attempt widescale renaming in the two major Chinese-controlled areas, Nanshi and Zhabei.

${ }^{37}$ SMA B11-2-145-20, Shanghai Shi Chengshi Jianshi Ju guanyu genggai yi 'Guominzheng' guanshou de fandong luming de qingshi baogao, 9 Aug. 1966; M.-C. Bergère, Sun Yat-sen (Stanford, 1998).
} 
interrupted by Japanese invasions in 1932 and 1937, the latter of which ended in eight years of occupation.

Japanese troops seized the foreign concessions in December 1941. In 1943, the Vichy government of occupied France abrogated its territorial claims in China in a gesture of solidarity with the Reorganized National Government of the Republic of China (1940-45), a puppet government installed by the Japanese, led by Wang Jingwei. The Americans and British followed suit, ceding nominal control of the International Settlement to their exiled allies, the Guomindang. In October that year, Wang's government renamed 240 roads in the former concessions that were deemed to be imperialistic or unpatriotic in meaning. Replacement names referred mainly to Chinese provinces, cities, mountains or rivers, following the established pattern of naming in the Settlement. Homophones, or near homophones, were preferred. For example, Hart Road, known as Hede Road in Chinese, became Changde Road, after the city in Hunan province. ${ }^{38}$ Gordon Road was renamed Jiangning Road, after a county in Jiangsu province.

Following Japan's defeat, the Guomindang government moved quickly to rename more than 80 roads in November-December 1945. Many roads that had been renamed under the Japanese reverted to their former titles. Others, especially in the former concessions, were newly rechristened after Guomindang heroes. The Bund became Zhongshan Dong Yi (Zhongshan East First) Road, after Sun Zhongshan. Avenue Joffre became Lin Sen Road after the chairman of the National Government from 1931 to 1943 (Lin Sen, 1868-1943). Amidst these changes, planners also sought to simplify road naming. Where possible, adjoined roads were merged into one longer stretch, divided into named sections indicating directions (north, south, east, west or central), reducing the number of names and facilitating navigation. ${ }^{39}$ The former Avenue Foch and the adjoining Avenue Edouard VII, for example, were amalgamated and renamed Zhongzheng Road, using the courtesy name of Jiang Jieshi. ${ }^{40}$

Before 'Liberation' in May 1949, therefore, Shanghai had already witnessed two major rounds of renaming. This had accomplished the puppet and Guomindang governments' shared goal of eliminating the majority of foreign road names, but had also caused great confusion. Names used in official contexts jarred with those deployed by people in everyday life. Well into the 1940s, for example, the three main parallel east-west roads to the south of the Da malu, were referred to by locals by numbers, beginning with the Er malu ('second road'), which was formally called Jiujiang Road, and ending with the Si malu ('fourth road'), officially named Fuzhou Road. Commercial publishers produced long lists of names to help people navigate the changing metropolis. ${ }^{41}$ After 1949, the CCP struck a more cautious balance between spatial inscription and the quotidian demands of municipal administration.

\footnotetext{
${ }^{38}$ Huang, 'Politics of street names', 150; SDZ, ch. 7, sect. 2.

${ }^{39} \mathrm{SDZ}$, ch. 7 , sect. 2 .

${ }^{40} \mathrm{~A}$ courtesy name is traditionally given to a Chinese man on reaching adulthood.

${ }^{41}$ SMA Y9-1-77-14, Shanghai shi xianghao lu tulu (shangong ditu), xia ce, luming suoyin, Mar. 1949.
} 


\section{After 'Liberation', 1949-53}

By the time that the CCP arrived in Shanghai, the party had developed a well-defined urban strategy centred on maintaining social and economic stability to prevent disorder. ${ }^{42}$ From the late 1920 s, the Communists had pursued agrarian revolution. This changed when, following a series of military victories, Mao Zedong announced in March 1949 that the 'centre of gravity of the Party's work has shifted from the village to the city'. ${ }^{43}$ Traditional accounts of the takeover portray the CCP as rustics, suspicious of the cosmopolitan cities and fearful of the challenges of urban governance. ${ }^{44}$ On the contrary, CCP leaders embraced cities as centres of industrial production and the home of the revolutionary proletariat. By harnessing cities' resources, the logic went, the CCP could defeat foreign imperialists and domestic reactionaries, and could create the material conditions needed for society to advance towards Communism. The party prioritized transforming 'consumerist' cities into centres of production that 'served the people'. ${ }^{45}$ In 1949, Shanghai was a city wracked by war and hyperinflation. The CCP leadership's instructions on urban management emphasized securing short-term stability above all else. ${ }^{46}$ The new government placed great emphasis on information gathering as a pre-requisite for action, carrying out mass surveys of every aspect of Shanghai's political, economic and cultural life before seizing the city in 1949, followed by a forensic neighbourhood-by-neighbourhood census in $1951 .{ }^{47}$ Policies and procedures adopted during the military takeover endured into the early 1950 s.

The goal of socialism was to improve lives and the CCP's urban management was geared towards this end. The Communists presented old Shanghai as an evil place, a place of 'foul wind and bloody rain, a place of darkness' to quote one children's book. ${ }^{48}$ This was a caricature, but there was some truth to the idea that the city was an unjust and uncaring place. Between 1915 and 1951, around one million exposed corpses and abandoned coffins were recovered by charitable organizations from the city's streets. ${ }^{49}$ In contrast, 'New Shanghai' was celebrated in three registers in the CCP's socialist realist propaganda: as a departure from the exploitative past; as an already existing model of good governance, in

\footnotetext{
${ }^{42}$ SMA A4-1-1, Zhonggong Shanghai Shi Zhengce Yanjiu Shi guanyu Chengshi jieguan gongzuo de jingyan baogao, 26 Jun. 1949.

${ }^{43}$ Mao Tse-tung, Report to the Second Plenary Session of the Seventh Central Committee of the Communist Party of China, 5 Mar. 1949, in Selected Works of Mao Tse-tung, vol. IV (Peking, 1969).

${ }^{44}$ N. Barber, The Fall of Shanghai: The Communist Take-Over in 1949 (London, 1979).

${ }^{45} \mathrm{~J}$. Werner, 'The making of mass society in Shanghai: the socialist transformation of everyday life, 19491958', University of Chicago Ph.D. diss., 2015.

${ }^{46}$ Mao, 'Telegram to the headquarters of the Luoyang Front after the recapture of the city', 8 Apr. 1948, in Selected Works, vol. IV, 247-9.

${ }^{47}$ SMA Y15-1-201, Shanghai Gaikuang, 1949; and SMA A4-2-11, Zhonggong Shanghai Shiwei Yanjiushi guanyu Yangpu qu jiben qingkuang diaocha, to SMA A4-2-29, Zhonggong Shanghai Shiwei Yanjiushi guanyu Changshu qu jiben qingkuang diaocha.

${ }^{48}$ Jiefangjun Shanghai Jingbeiqu, Jiefang Shanghai de Gushi (The Story of the Liberation of Shanghai) (Shanghai, 1980), 10.

${ }^{49} \mathrm{C}$. Henriot, 'Invisible deaths, silent deaths: "bodies without masters" in Republican Shanghai', Journal of Social History, 43 (2009), 407-37, at 415.
} 
which citizens could lead productive and healthy lives; and as a promised utopia. $^{50}$

In practical terms, a small number of iconic Shanghai sites were repurposed with great fanfare, including the site of the former Shanghai Racecourse which became the People's Square in 1952. ${ }^{51}$ The first prestige project was completed in 1955: the towering Sino-Soviet Friendship Building, a gift to the city from the USSR. ${ }^{52}$ Beyond this, state resources were mostly invested in the construction of industrial districts and worker housing. In this vein, in 1951, Caoyang New Village was opened as a showcase for the benefits of the new society. ${ }^{53}$ Model worker housing served a dual purpose as a solution to Shanghai's overcrowding, and as a representation of the government's concern for the workers. The most famous housing project was the transformation of the Fangua Lane slum to a modern development in $1964 .^{54}$ Beyond these high-profile projects, inequality persisted, and the broader pattern of urban transformation was one of moderate, rather than fundamental, change.

Renaming was guided by instructions from the party centre. Mao had instructed those in leading positions to 'guard against arrogance' in March 1949, forbidding the naming of places, streets or enterprises after party leaders. ${ }^{55}$ This injunction endures to the present day. In December 1951, the State Council declared that only three types of road names should be changed, to prevent economic and social disruption: those named for domestic or foreign 'reactionaries'; those that 'discriminated against ethnic minorities'; and those that were confusing (including duplicates). All significant changes were to be discussed at local People's Consultative Conferences and referred to the Ministry of the Interior for approval. ${ }^{56}$ The State Council ordered that renamed streets were to be called after China's provinces, cities and autonomous regions. ${ }^{57}$

The guiding principle was to 'uphold custom and elevate the nation' ${ }^{58}$ Most Chinese cities have a few prominent thoroughfares with revolutionary names, including Jiefang (Liberation) Road, and Renmin (People's) Road, but because the State Council's instructions were followed nationwide, China's cities exhibit a relatively uniform pattern of naming based on Chinese geography and local landmarks. This echoed the naming and renaming practices developed in Shanghai during the colonial period. Yao Xiaoyi and Cai Junmei have suggested that the adoption of this pattern elsewhere in China was due to Shanghai's outsized influence. ${ }^{59}$ Although there is no direct evidence that the State Council's decision to use

\footnotetext{
${ }^{50}$ On Chinese socialist realism, see S.R. Landsberger, 'Mao as the kitchen god: religious aspects of the Mao cult during the Cultural Revolution', China Information, 11 (1996), 196-214, at 199-200.

${ }^{51}$ Xiong Yuezhi, 'From racecourse to People's Park and People's Square: the historical changes and the symbolic meaning', Frontiers of History in China, 3 (2008), 101-16.

${ }^{52} \mathrm{SDZ}$, Dashiji.

${ }^{53}$ Chonglan Fu and Wenming Cao, An Urban History of China (Basingstoke, 2009), 117-28.

${ }^{54} \mathrm{Ho}$, Curating Revolution, $60-102$.

${ }^{55}$ Mao, 'Methods of work of party committees', 13 Mar. 1949, in Selected Works, vol. IV.

${ }^{56}$ SMA B1-1-1134, Zhengwuyuan guanyu genggai diming de zhishi, 1951.

${ }^{57}$ SMA A52-2-340-22, Shanghai Shi Chengshi Jianshi Ju guanyu xitong de genggai Shanghai shi daolu luming qing tigong yijian de han, 25 Jul. 1958.

${ }^{58}$ Zhang, 'Shanghai jiedao mingcheng', 81-2.

${ }^{59}$ Yao and Cai, 'Shanghai chengshi jiedao', 150-3.
} 
geographical names was based on the Shanghai model, it is not unreasonable to infer that this may have been the case. This spatial inscription was not ideologically neutral: writing the nation onto local maps promoted national consciousness over local distinctiveness. ${ }^{60}$

The State Council's instructions ensured that there was no widescale renaming in early 1950s Shanghai. Responsibility for road naming was held by the Municipal Construction Bureau, with oversight from the higher echelons of the city government. ${ }^{61}$ In March 1950, Mayor Chen Yi wrote to the State Council asking permission to change the names of some roads and parks in the city named after Guomindang leaders, noting that nothing had yet been done in this regard. ${ }^{62}$ Permission was granted and the decision was announced in May. ${ }^{63} \mathrm{~A}$ total of 16 roads were renamed, 13 of which were named after Guomindang figures. ${ }^{64}$ The CCP chose to rename these roads after important places in the party's history, projecting their revolutionary mythology on to Shanghai's cityscape while sticking to the State Council's instructions to use geographical names: Zhongzheng Road became Yan'an Road, named after the CCP's remote wartime headquarters; Qimei Road became Siping Road, after the location of a series of crucial battles in north-east China that turned the course of the Chinese Civil War; and Lin Sen Road became Huaihai Road after the decisive military campaign that secured the CCP's victory. ${ }^{65}$ The State Council had ruled that streets named after politically acceptable individuals need not be changed, so the names of the three roads named after Sun Zhongshan endured because the Communists also claimed him as the father of their revolution. Similarly, the name of Huang Xing Road was not changed until 1964. Nine other roads were renamed later that year, but only one for political reasons: a branch of Qimei Road that had been missed previously. ${ }^{66}$

Beyond politics, the expense of road renaming may also have discouraged the practice. New signs would have to be made and installed, with the old ones disposed of. This was a costly business. There were indirect costs too, including updating information held by government departments, amending maps and lists, and informing people of the changes. Local businesses and residents would incur costs, including updating shop signs, stationery and advertisements.

\footnotetext{
${ }^{60}$ Huang, 'Politics of street names', 156. More than 170 roads were built in Shanghai between 1951 and 1958. Each district adopted a geographical region of China from which names were drawn, roughly analogous with its location in the city: north-eastern Yangpu district adopted place names from China's north-eastern Dongbei region, for example, and Pudong district, in the east, drew on names from Shandong province in eastern China.

${ }^{61} \mathrm{SDZ}$, ch. 7 , sect. 2.

${ }^{62}$ SMA B1-2-750-2, Shanghai Shi Renmin Zhengfu guanyu genggai ben shi ge daolu ji gongyuan mingcheng de baogao, 28 Mar. 1950.

${ }^{63} \mathrm{SDZ}$, Appendix 2, Shanghai Shi Renmin Zhengfu gonggao Shanghai shi xin ding ruogan tiao dao lu ji gongyuan mingcheng, 25 May 1950.

${ }^{64}$ This also included Weidemai Road, named after General Albert Wedemeyer, the commander of American forces in China between 1944 and 1945. Of the 16 roads renamed, 10 were geographical subdivisions of four longer roads. Zhongzheng Central, East and West Roads, for example, have been counted separately.

${ }^{65}$ French, Old Shanghai, 69.

${ }^{66} \mathrm{SDZ}$, Dashiji.
} 
Caution defined road renaming in Shanghai until 1954. Only seven roads were renamed in 1951, five for administrative reasons, including to eliminate homophones. Two changes in 1951 were politically inspired: Minguo (Republic) Road (formerly the Boulevard Republique des Doux), which was renamed Renmin (People's) Road; and Dugao Road, so named because it was home to the ancestral temple of the notorious Green Gang leader Du Yuesheng. The latter was changed to a near-homophone. Only two names were changed in 1952, one of which was left over from the colonial period Keming (formerly 'Cunningham') Road. Eight changes were made in 1953, with the majority being for routine administrative reasons. $^{67}$

Some renaming in the early 1950s was representative of changing political realities. For example, in January $1954 \mathrm{Bi}$ Jiao Road, the site of a large prison, was renamed. Its name derived from the proverb ming xing bi jiao meaning 'deploy criminal punishment to educate people to obey the law'. The new name was Xi Qin (Study Industriousness) Road, in reference to the CCP's emphasis on 'reforming' offenders through labour and political study. ${ }^{68}$ Aside from the names of a few important thoroughfares, however, very little had changed in terms of road names between 1949 and 1953. Of a list of 415 former International Settlement and French Concession roads compiled by the CIA in June 1953, the names of only 13 had been changed from those used under the Guomindang. ${ }^{69}$ Most renamed roads were located in the city centre. As Pan Tianshu and Liu Zhijun have noted, renaming had little bearing on the city's 'lower orders' who lived in industrial or squatter districts far from the city centre. ${ }^{70}$

\section{The Shanghai City Master Plan, 1954}

The first bout of widescale renaming of roads in socialist Shanghai came in 1954, in response to national developments. In 1953, the country embarked on a 'transition to socialism' under the First Five Year Plan. A radical vision for the city's socialist future was drawn up to mark this major shift in state-society relations. On 25 March 1954, the Municipal Construction Committee published its first co-ordinated plan for urban development, the Shanghai City Master Plan, which established city-wide priorities for building and redevelopment. ${ }^{71}$ It offered an ambitious vision for a socialist city that prioritized production and improved living standards. ${ }^{72}$ The single largest renaming of Shanghai's roads to date followed, in

\footnotetext{
${ }^{67} \mathrm{SDZ}$, Appendix 2, qingkuang baogao, 2 May 1964. Cunningham Road was named for an American diplomat.

${ }^{68} \mathrm{SDZ}$, Dashiji.

${ }^{69}$ Central Intelligence Agency CREST archive, National Archives and Records Administration II, College Park, Maryland. Information Report: Shanghai Street Names, 8 Jun. 1953.

${ }^{70}$ Pan Tianshu and Liu Zhijun, 'Place matters: an ethnographic perspective on historical memory, place attachment, and neighborhood gentrification in post-reform Shanghai', Chinese Sociology \& Anthropology, 43 (2011), 52-73, at 62-3.

${ }^{71}$ Known as the Shanghai Chengshi Zongti Guihua in Chinese. Shanghai chengshi guihua zhi bianzuan weiyuanhui (eds.), Shanghai Chengshi Guihua Zhi (Gazeteer of Shanghai City Planning) (Shanghai, 1999), Dashiji (Chronicle of Events). URL: www.shtong.gov.cn/Newsite/node2/node2245/node64620/index.html, accessed 27 Jul. 2020.

${ }^{72}$ Shanghai Chengshi Guihua Zhi, ch. 2, sect. 1, part 3.
} 
December 1954, with 58 names changed. ${ }^{73}$ Some were obviously selected due to their names being considered inappropriate, but more prosaic reasons informed the majority of choices.

Aside from replacing names that were duplicates, homophones, easily confused or too long, there were four main administrative rationales for changing names. The first was that a large number did not follow the pattern of east-west roads being named after cities and north-south roads being named after provinces. For instance, Wenchang Road, which ran north to south, was named after a city. It was renamed Wen'an Road, after a county. The second reason was that some roads used anachronistic place names: Fengtian Road bore the old name for Liaoning province, for example; and Kulun Road bore the old name for Ulan Bator, the capital of Mongolia, which had secured independence from China in 1921. The latter was not only an anchronism, therefore, but also anomalous as a street named after a foreign capital. Remarkably, Lundun (London) Road had also survived waves of Nationalist and Communist renaming. ${ }^{74}$ The third administrative reason for changing road names was that some had suffixes that did not reflect their relative size or importance. Fourth, many roads were named after landmarks that were either no longer present, or considered anachronistic. ${ }^{75} \mathrm{~A}$ very few other roads were renamed for political reasons, including a small number with obvious links to the Guomindang. This included Minsheng (People's Livelihood) Road, the name of which alluded to one of Sun's Three People's Principles. ${ }^{76}$ Renaming was often imperfectly executed. In 1959, for example, the editors of Jiefang Ribao received a letter from a local asking why there was still a Lundun (London) in Shanghai when the imperialists had long been chased out. In their reply, the Bureau pointed out that this road had already been renamed in December 1954, but the old road sign had not been taken down. ${ }^{77}$

Of course, renaming could often be both politically desirable and administratively necessary. One of the eight roads renamed in 1955 was Shi Zhengfu (Municipal Government) Road, in Xuhui district. It had acquired this name because it was home to the Guomindang's government administration between 1927 and 1933. The existence of the name was potentially confusing as the current government's headquarters was located elsewhere. ${ }^{78}$

Road renaming in the mid-1950s was targeted at removing only the most egregious references to the old society, alongside a need to systematize naming. One of the four roads renamed in 1956 was Ma Yushan Road, named after a businessman who had developed the road as part of his horse racing and stabling business. The

\footnotetext{
${ }^{73} \mathrm{SDZ}$, Dashiji. Six roads had also been renamed earlier in the year.

${ }^{74} \mathrm{SDZ}$, Dashiji.

${ }^{75}$ This included, for example, Zhangchuan Road, which was named for a gate in the wall of the old Chinese city that no longer stood.

${ }^{76}$ Minsheng Road was renamed Minhe Road, after a county in Qinghai. SDZ, Appendix 2, Shanghai Shi Chengshi Jiansheju shangbao Shirenwei guanyu genju Wang Suici deng jianyi bu yao suibian genggai diming an jinxing diaocha chuli de qingkuang baogao, 2 May 1964.

${ }^{77}$ SMA B257-1-938, Shanghai Shi Renmin Wei Bangongting yu Jiefang Ribao deng danwei guanyu chaozhuan jianyi yu genggai luming de renmin laixin, Mar. to Nov. 1959.

${ }^{78} \mathrm{SDZ}$, Dashiji. The seven other changes made that year were minor administrative changes, including correcting an erroneously written character in one name.
} 
area's district committee recommended to the Construction Bureau that the road be renamed because they 'believe[d] that on liberated ground this type of person's name should not be preserved as a road name'. The decision was rationalized by pointing out that the road could be amalgamated at both ends into existing roads, making naming in the area more logical. ${ }^{79}$ This suggestion was approved because it suited the local government's twin aims of eliminating 'semi-feudal' legacies and systematizing naming.

\section{The late 1950s}

Urban planning assumed a new importance in late 1950s Shanghai. In April 1956, Mao Zedong delivered a major speech titled 'On the Ten Major Relationships' which signalled a shift towards fast-paced socialist transformation. Mao placed new emphasis on harnessing the economic power of China's coastal cities and local officials scrambled to respond. ${ }^{80}$ Shanghai officials produced an ambitious new plan for urban development, which was approved in 1958. That year, Mao commanded that China should undertake a 'Great Leap Forward', rapidly developing agriculture and industry. To support the Leap, an even more radical urban plan was adopted. Under the new plan, the 'Leap' in production was to be linked to improvements in all areas of urban life, including constructing satellite towns, clearing slums, relocating industrial districts, increasing green space and constructing roads. Planners considered the city's roads too narrow and winding, so a network of widened arterial avenues was laid out. Highways were built to connect to the surrounding satellite towns and other regional cities. ${ }^{81}$

Even during the radical year of 1958, however, road renaming in Shanghai was limited. The Construction Bureau received a slew of letters from newspaper readers on the subject of renaming roads to remove cultural impediments to production, forwarded by the editorial offices of newspapers Jiefang Ribao and Wenhui $B a o{ }^{82}$ Letters to editors were an approved means of expressing a degree of criticism of government organizations, and an avenue through which citizens could demonstrate their own revolutionary credentials. ${ }^{83}$ In response, the Bureau identified 39 roads in need of immediate renaming. Of the 39 , only 10 were deemed 'inappropriate for the socialist system' because they had associations with the Guomindang, including those with the characters Guo, Min or Zheng. The rest were to be renamed because of the need to systemize and rationalize in the name of production. $^{84}$

\footnotetext{
${ }^{79}$ SMA B257-1-212, Shanghai Shi Shizheng Gongcheng Ju guanyu genggai Shuangyung, Yingkou luming de han, 16 May 1956.

${ }^{80}$ Mao Tse-tung, 'On the Ten Major Relationships', 25 Apr. 1956, in Selected Works of Mao Tse-tung, vol. V (Peking, 1977).

${ }^{81} \mathrm{Zhu}$, 'Socialist suburbanization', 229-31.

${ }^{82}$ SMA A52-2-340-22.

${ }^{83}$ In July 1949, one citizen had suggested renaming Zhongzheng Road as Jiang Fei (Bandit Jiang) Road, so that people could stamp on Jiang Jieshi's memory. SMA B1-2-750-4, Lu Fasheng guanyu jianyi 'Zhongzheng Lu' gaiwei 'Jiang Fei Lu' de baogao, 1 Jul. 1949. On letters, see L.M. Luehrmann, 'Facing citizen complaints in China, 1951-1996', Asian Survey, 43 (2003), 845-66.

${ }^{84}$ SMA A52-2-340-22.
} 
Eventually, only 15 of these roads were renamed in 1958. In December that year, 10 roads that were renamed were located in the area designed to be the Guomindang's administrative centre. These included two named for aspects of Guomindang political philosophy: Sanmin Road, the name of which alluded to the Three People's Principles; and Wuquan Road referring to Sun's concept of the 'Separation of Five Powers'. The other eight names indicated a geographical position relative to the Guomindang's government administration compound. Ultimately, the pattern of road renaming in 1958 was similar to that of 1957 (nine roads) and 1959 (four). ${ }^{85}$

\section{'Superstitious names': the early 1960s}

The radicalism that accompanied the launch of the Socialist Education Movement in 1964 saw a new wave of calls for changing 'leftover feudal, superstitious and colonial names'. The Bureau conducted another survey in May 1964 and identified 213 problematic road names. ${ }^{86}$ The fact that so many were considered inappropriate at this time speaks to how little had been done previously. ${ }^{87}$ The Bureau's selection included: roads with 'the obvious colour of feudalism and superstition'; roads with inappropriate peoples' names, like Huang Xing Road; those with problematic references to the old culture, and roads named after colonial landmarks, including Tiyuhui (Sports Club) Road, which was named after the former British club; Tianzhu Tang (Catholic Church) Street; and Yihe Road, named after the British trading firm Jardine, Matheson \& Co. The central government had warned again in February 1964 against renaming roads without good grounds. With reference to the State Council's 1951 injunction, it was decided that only 61 very inappropriate names would be changed. Amongst these, 40 were considered problematic because they had religious connotations, chiefly referring to Buddhist, Christian, Daoist, and Muslim places of worship. Names continued to be changed as little as necessary to remove the offending aspect, with geographical names preferred. Sanguantang Road, named for its Daoist temple, for example, was renamed Sanmenxia Road after a city in Henan province. The 21 other names that were changed had capitalist, 'reactionary' or colonial connotations, including Diandang (Pawnshop) Street, and Yingui Road, named for 'local strong man' Wang Yingui. Huang Xing Road was renamed Ningguo Road (after a city in Anhui). ${ }^{88}$

Although the ideological climate of 1964 was more radical, the Construction Bureau again stopped short of altering all road names identified as problematic. Policy was by no means to change anything that offended revolutionary sensibilities, even when called upon to do so by 'the masses'. For example, a resident had written to complain about the derogative names of Sha Zhu (Pig Slaughter)

\footnotetext{
${ }^{85}$ SDZ, Dashiji, Appendix 2, qingkuang baogao, 2 May 1964.

${ }^{86}$ SMA B11-1-12-157.

${ }^{87}$ SMA B11-2-80-82, Shanghai Shi Chengshi Jianshi Ju guanyu genggai Shanghai Shi bufen fengjian mixin he zhimindi canyi luming, dianming, changing de qingshi baogao, 26 Jun. 1964.

${ }^{88}$ SMA B11-1-12-157; SDZ, ch. 7, sect. 2; Appendix 2, Shanghai Shi Chengshi Jianshe Ju guanyu genggai Sanguangtang $L u$ deng 61 tiao luming de tongzhi, 12 Aug. 1964.
} 
Lane and Gou Rou (Dog Meat) Lane in April 1963. ${ }^{89}$ Similar complaints were received about the name of Rubbish Pool Street in May 1963 and September 1964..$^{90}$ The Bureau refused these requests, explaining that because 'some road names are shaped down through history, and the names are already very familiar to the local residents' ${ }^{91}$ This was in line with the State Council's instructions against unnecessary renaming. It was not until after Lu Liang's May 1966 letter that Rubbish Pool Street's name was finally changed (becoming Fukang North Road). ${ }^{92}$ Lu had deployed the language of the Patriotic Hygiene Campaign, suggesting that the name implied that the street was an unsanitary place..$^{93}$

\section{The Cultural Revolution and after}

On 8 August 1966, the Central Committee passed a 'Decision concerning the Great Proletarian Cultural Revolution', calling for the masses to organize themselves to overthrow those in power 'taking the capitalist road', and to transform all aspects of culture that were 'not in correspondence with the socialist economic base, so as to facilitate the consolidation and development of the socialist system'. ${ }^{44}$ In Shanghai, Red Guards took to the streets determined to 'destroy the four olds' (customs, culture, habits and ideas). This escalated from accosting people in the streets due to their dress or hairstyle, to widespread murder, assault, arbitrary detention and the ransacking of private homes.

The Cultural Revolution gave radicals the opportunity to act out against perceived conservatism in all fields of governance, including urban administration. ${ }^{95}$ Bureaucrats' inability to properly address the issue of road naming was understood as an example of conservatism in action. Red Guards took renaming upon themselves. In Huangpu district, the city's commercial heartland, Red Guards tore down 93 per cent of shop signboards (2,166 of 2,328), and renamed restaurants, schools and hospitals. Red Guards took Nanjing Road as their revolutionary

\footnotetext{
${ }^{89}$ SMA B257-1-3440-104, Jiefang bao zhuan Lao Ximen jiuhuo shangdian zhigong guanyu fanying xuduo luming chenjiu jianyi you fanxin zhi biyao de wenjian, 14 Apr. 1963. The official names of these two roads had already been changed to near-homophones: Sazhu (Immortal Pearl) Lane and Gouyu (Curved Jade) Lane. The letter writer complained that the old names had endured because homophones had been used.

${ }^{90}$ SMA B257-1-3440-144, Xinmin Wanbao baozhuan Mao Jingding guan yu jianyi Pudong Yangjiadu Laji Tang Jie genggai Fukang Bei Lu qing Jianzhu Guanli Chu yanjiu chuli de han, 31 May 1963; SMA B257-1-3834-247, Shanghai shi chengshi jianshe ju chuli Yang Ting jianyi genggai Laji Tang Jie luming laixin de wenjian, 11 Sep. 1964.

${ }^{91}$ SMA B257-1-3440-147, Shanghai Shi Chengshi Jianshe Ju guanyu jianyi Laji Tang Jie gaiming wenti de fuhan, 18 Jun. 1963.

${ }^{92}$ There is a degree of uncertainty concerning when exactly Rubbish Pool Street was renamed. SDZ lists the change as taking place in 1958 in its chronology, but in 1964 in Appendix 2, qingkuang baogao, 2 May 1964. Archival records show that the name was finally changed in 1966; SMA B11-2-145-12, Shanghai Shi Renmin Weiyuanhui Gongyong Shiye Bangongshi guanyu genggai Laji Tang Jie de pifu, 3 Jun. 1966. It is possible that there was more than one road with this name.

${ }^{93}$ On the campaign, see R. Rogaski, Hygienic Modernity: Meanings of Health and Disease in Treaty-Port China (Berkeley, 2004), 373-92.

${ }^{94}$ 'Decision of the Central Committee of the Chinese Communist Party concerning the Great Proletarian Cultural Revolution', Peking Review, 9, 12 Aug. 1966, 6-11.

${ }^{95}$ E.J. Perry and Li Xun, Proletarian Power: Shanghai in the Cultural Revolution (Boulder, 1997).
} 
headquarters, laying claim to Shanghai's most famous commercial boulevard by renaming it Fandi (Anti-Imperialism) Street. ${ }^{96}$

Across China, signs bearing old road names were vandalized. ${ }^{97}$ Renaming was a creative act, but it was performed within a political context that demanded orthodoxy. Elizabeth Perry and Li Xun have argued that the Cultural Revolution witnessed the creation of a new revolutionary language, characterized by a tendency to reduce everything to 'red' (good) or 'black' (bad). They note a 'peculiar uniformity' to this language, stemming from the centralization of political power: new forms echoed slogans disseminated by Mao and his followers. ${ }^{98}$ In Beijing, some 475 streets were renamed to incorporate the word 'revolution', and there were more than 27 Red Sun Roads. ${ }^{99}$ Shanghai saw a profusion of Dongfang Hong (East is Red) Streets, amongst others. This chaotic approach was considered by the Shanghai Revolutionary Committee's Transportation Group to be very inconvenient for production and daily life.'. ${ }^{100}$

Bitter power struggles were fought in every work unit, impairing the local government's ability to carry out ordinary administration. In August 1966, the Construction Bureau had drafted a report on road names in the city, on the grounds that previous rounds of changes had not been radical enough. It recommended finally purging the legacies of the reactionary government, including changing the names of 40 roads which included any of the three characters Guo, Min or Zheng (identified, but unchanged, in 1958). ${ }^{101}$ A meeting of senior city leaders was convened in October to discuss this proposal, but it ended without a resolution. ${ }^{102}$

In January 1967, radicals overthrew the local government in Shanghai and established the Shanghai People's Commune. It was replaced after only a month with a tri-partite Red Guard-Army-Party alliance designed to ensure that government could function. This new government, the Shanghai Revolutionary Committee, remained radical in its ambitions. In April, the Committee's Communications Group recommended to the leadership that Zhongshan Dong Yi (Zhongshan East First) Road, which was home to the colonial architecture of the Bund, be renamed Fandi (Anti-Imperialism) Street. They also suggested that Tianmu Road in Zhabei be renamed Hongweibing (Red Guard) Road because its name was a reminder of superstition (in Buddhism, Tianmu is the Heavenly Mother). However, even the Revolutionary Committee's leadership adhered to the principle

\footnotetext{
${ }^{96}$ Shanghai Shi Huangpu Quzhi Buanzuan Weiyuanhui, Huangpu Quzhi (Shanghai, 1996), ch. 41, 'Wenhua Dageming' Jilüe, sect. 2: 'Hongweibing' naoshi 'sao sijiu'. URL: http://shtong.gov.cn/Newsite/ node2/node4/node2249/huangpu/node36258/node62519/index.html, accessed 27 Jul. 2020.

${ }^{97} \mathrm{Li}$, Zhongguo chengshi jieming, 34-5.

${ }^{98}$ Elizabeth J. Perry and Li Xun, 'Revolutionary rudeness: the language of Red Guards and rebel workers in China's Cultural Revolution', in Jeffrey N. Wasserstrom (ed.), Twentieth-Century China; New Approaches (London, 2003), 221-36.

${ }^{99}$ Yang Dongping, Chengshi Lifeng: Beijing he Shanghai wenhua jingshen (City Monsoon: The Spiritual Culture of Beijing and Shanghai) (Beijing, 1994), cited in Michael Dutton, Streetlife China (Cambridge, 1998), 168.

${ }^{100}$ SMA B246-2-154-1, Shanghai Shi Geming Weiyuanhui Shizheng Jiaotong Zu guanyu genggai luming de yijian, 28 Apr. 1967.

${ }^{101}$ SMA B11-2-145-20.

${ }^{102} \mathrm{SDZ}$, Dashiji.
} 
that road names should be changed as little as possible. The Committee put off a decision, suggesting that the matter should be taken to the masses for discussion. ${ }^{103}$ During 1967-69, only 13 roads were officially renamed in Shanghai, all of which standardized or simplified existing names. The masses took renaming into their hands in 1966, but Shanghai witnessed little officially sanctioned renaming during the Cultural Revolution as bureaucrats stuck to the principles observed in the 1949-66 period.

There was no further official renaming until October 1980, when the city government was beginning to dismantle the commune system, neccessitating minor changes. Three road names, including Huang Xing Road, that had been changed in 1964 were restored in March 1985. ${ }^{104}$ A noteworthy proportion of roads in Jiangwan retain Guomindang-era names today. ${ }^{105}$

\section{Conclusion}

This article has argued that Cultural Revolution-era unofficial renaming practices have shaped ideas about revolutionary change in socialist Shanghai that are not reflective of the period 1949-66. During this time, officials often considered widescale road renaming, but scaled back their ambitions at each stage, in line with instructions from Beijing and with their pragmatic approach to urban management more generally. Renaming represented symbolic change, differentiating virtuous 'New Shanghai' from the evil old society, yet the nature and extent of renaming in the city was relatively conservative.

Road renaming was driven in large part by a desire to rationalize the city, unleashing its productive power. The ideal of improvement through modernization was a major motivating factor in CCP governance, especially given the extremes of inequality that defined urban life before 1949. This is not to deny the destructive despotism at the heart of the Maoist project, but rather to explain that modernization was also an important component of CCP ideology in the Mao era, a fact that is often overlooked. Finally, we should note that when renaming did take place, rather than turning the city 'red', the colonial-era practice of using Chinese place names was usually deployed, writing the national future over the city's past.

The CCP's desire to rationalize Shanghai re-emerged after the Cultural Revolution. In 1978, China was set on a new course of 'reform and opening up' through rapid economic development, which has driven urbanization at a pace unprecedented in human history. In this context, technocratic governance has assumed a new importance and the management of place names captures this trend. In response to a nationwide strategy, Shanghai municipality set up a Place Names Office in July 1979, charged with restoring proper management of naming. A multi-layered infrastructure was set up to monitor names down to neighbourhood level. ${ }^{106}$ The creation of this infrastructure demonstrated the importance

\footnotetext{
${ }^{103}$ SMA B246-2-154-10, Shanghai Shi Geming Weiyuanhui Bangongshi guanyu genggai luming de baogao, 3 May 1967.

${ }^{104} \mathrm{SDZ}$, Dashiji, ch. 7, sect. 1. On post-Cultural Revolution renaming beyond Shanghai see Li, Zhongguo chengshi jieming, 17-22.

${ }^{105}$ Yao and Cai, 'Shanghai chengshi jiedao', 153.

${ }^{106}$ SDZ, Dashiji, ch. 7, sect. 1.
} 
attached by central and local government to the proper management of place names for effective governance.

This was accompanied by a concerted effort to survey and systematize road names. In April 1979, a trial census of place names was launched in Nanshi district, checking existing names, recording new ones and using the data to produce detailed city maps. In August, the Office announced the commencement of the city's first citywide place name census. It took 19 months to complete and identified 2,890 road names. In October 1980, 51 road names were changed in response to survey findings, mostly for routine administrative reasons. ${ }^{107}$

Place name management was given even more importance as Shanghai grew in the following decades. In September 1989, a Shanghai Place Names Committee was established to co-ordinate a citywide place name management network across 17 different organizations. A visit by Deng Xiaoping in 1992 spurred further reforms, and the city resumed its place as China's economic capital. In December that year, place name offices were set up in every city district. ${ }^{108} \mathrm{~A}$ second major survey ran between February 1991 and November $1994 .{ }^{109}$ In this way, a place naming management bureaucracy has brought order to naming practices in hyper-modern Shanghai, completing a project begun in the 1950s. ${ }^{110}$

Similar tensions regarding renaming played out in other Chinese cities in the Maoist period, but not to the same extent. The significance of renaming in Shanghai was magnified by the prominence the city was given by the CCP as a proving ground for the transformative power of socialism to do away with the legacies of the 'semi-colonial, feudal and reactionary' past. Future research may explore renaming in other cities, as well as the important issue of how residents experienced renaming, and whether old names bearing meaning to Shanghainese people endured in popular memory.

\footnotetext{
${ }^{107}$ SDZ, Dashiji, ch. 7 , sect. 3.

${ }^{108} \mathrm{SDZ}$, ch. 7 , sect. 1 , sect. 2 .

${ }^{109} \mathrm{SDZ}$, Dashiji, ch. 7, sect. 3. The total number of roads registered was 3,687.

${ }^{110}$ Yao and Cai, 'Shanghai chengshi jiedao', 152; Zhang, 'Shanghai jiedao mingcheng', 104. The development of the Pudong New Area and Waigaoqiao Free Trade Zone has seen the re-emergence of roads named after foreign people, places and companies, including: Niudun (Newton), Ying Lun (London, Britain) and Xunda (Schindler) roads.
}

Cite this article: Howlett JJ (2022). Ordering the city: revolution, modernity and road renaming in Shanghai, 1949-1966. Urban History 49, 612-630. https://doi.org/10.1017/S0963926821000249 